\title{
CD36 promotes vasculogenic mimicry in melanoma by mediating adhesion to the extracellular matrix
}

Carmela Martini ${ }^{1,2 \dagger}$, Mark DeNichilo ${ }^{1 \dagger}$, Danielle P. King ${ }^{1}$, Michaelia P. Cockshell ${ }^{1}$, Brenton Ebert ${ }^{1}$, Brian Dale ${ }^{2}$, Lisa M. Ebert ${ }^{1}$, Anthony Woods ${ }^{2}$ and Claudine S. Bonder ${ }^{1,3^{*}}$

\begin{abstract}
Background: The formation of blood vessels within solid tumors directly contributes to cancer growth and metastasis. Until recently, tumor vasculature was thought to occur exclusively via endothelial cell (EC) lined structures (i.e. angiogenesis), but a second source of tumor vasculature arises from the cancer cells themselves, a process known as vasculogenic mimicry (VM). While it is generally understood that the function of VM vessels is the same as that of EC-lined vessels (i.e. to supply oxygen and nutrients to the proliferating cancer cells), the molecular mechanisms underpinning VM are yet to be fully elucidated.

Methods: Human VM-competent melanoma cell lines were examined for their VM potential using the in vitro angiogenesis assays (Matrigel), together with inhibition studies using small interfering RNA and blocking monoclonal antibodies. Invasion assays and adhesion assays were used to examine cancer cell function.

Results: Herein we demonstrate that CD36, a cell surface glycoprotein known to promote angiogenesis by ECs, also supports VM formation by human melanoma cancer cells. In silico analysis of CD36 expression within the melanoma cohort of The Cancer Genome Atlas suggests that melanoma patients with high expression of CD36 have a poorer clinical outcome. Using in vitro 'angiogenesis' assays and CD36-knockdown approaches, we reveal that CD36 supports VM formation by human melanoma cells as well as adhesion to, and invasion through, a cancer derived extracellular matrix substrate. Interestingly, thrombospondin-1 (TSP-1), a ligand for CD36 on ECs that inhibits angiogenesis, has no effect on VM formation. Further investigation revealed a role for laminin, but not collagen or fibronectin, as ligands for CD36 expressing melanoma cells.

Conclusions: Taken together, this study suggests that CD36 is a novel regulator of VM by melanoma cancer cells that is facilitated, at least in part, via integrin- $a_{3}$ and laminin. Unlike angiogenesis, VM is not perturbed by the presence of TSP-1, thus providing new information on differences between these two processes of tumor vascularization which may be exploited to combat cancer progression.
\end{abstract}

Keywords: CD36, Vasculogenic mimicry, Melanoma, Tumor microenvironment, Thrombospondin, Laminin, Integrin

\footnotetext{
*Correspondence: claudine.bonder@unisa.edu.au

${ }^{\dagger}$ Carmela Martini and Mark DeNichilo contributed equally to this work.

${ }^{1}$ Centre for Cancer Biology, University of South Australia and SA Pathology,

Adelaide, South Australia, Australia

${ }^{3}$ Adelaide Medical School Faculty of Health and Medical Sciences, The

University of Adelaide, Adelaide, South Australia, Australia

Full list of author information is available at the end of the article
}

C C The Author(s). 2021 Open Access This article is licensed under a Creative Commons Attribution 4.0 International License, which permits use, sharing, adaptation, distribution and reproduction in any medium or format, as long as you give appropriate credit to the original author(s) and the source, provide a link to the Creative Commons licence, and indicate if changes were made. The images or other third party material in this article are included in the article's Creative Commons licence, unless indicated otherwise in a credit line to the material. If material is not included in the article's Creative Commons licence and your intended use is not permitted by statutory regulation or exceeds the permitted use, you will need to obtain permission directly from the copyright holder. To view a copy of this licence, visit http://creativecommons.org/licenses/by/4.0/. The Creative Commons Public Domain Dedication waiver (http://creativecommons.org/publicdomain/zero/1.0/) applies to the data made available in this article, unless otherwise stated in a credit line to the data. 


\section{Background}

Angiogenesis is the most common mechanism by which tumors become vascularized and metastasize. However, the growing mass can also utilise other processes to form vascular networks, such as vasculogenic mimicry (VM). First identified in aggressive uveal melanoma cells, VM has since been seen in several aggressive malignancies such as glioblastoma [1-3], colorectal cancer [4, 5], breast cancer $[6,7]$, ovarian cancer $[8,9]$, pancreatic cancer [10] and prostate cancer [11]. VM occurs when highly aggressive malignant cells undergo cellular phenotypic changes to resemble endothelial cells (ECs) which form the inner lining of all vasculature. While these malignant cells display EC markers, i.e. vascular endothelial (VE)-cadherin, ephrin receptor A2 (EphA2) and E-selectin, and like ECs can secrete many basement membrane relevant proteins, they do however have little to no expression of EC-specific proteins such as CD31 (PECAM-1) and TIE-2 [12, 13]. Histological staining with the periodic acid-Schiff stain (PAS, recognizing basement membrane proteins) used in conjunction with an antibody to CD31 is the universally accepted protocol to distinguish VM structures as PAS-positive/CD31negative from the EC-lined PAS-positive/CD31-positive vasculature [14-16].

The aggressive nature of VM is supported by evidence of these structures anastomosing with traditional EClined tumor vasculature [17]; and in doing so, it further enables the solid tumor mass to gain access to oxygen and nutrients for growth [18]. VM content in tumors is undeniably an indicator of poor patient prognosis, including metastatic disease and overall survival [16, 19]. Meta-analyses of different cancer types show that patients with tumors that are high in VM content have a significantly lower 5-year overall survival rate when compared to those with little/no VM content [20]. Despite the similarities between angiogenesis and VM, current anti-angiogenic approaches fail to target VM vascular structures and indeed the use of antiangiogenic therapy (bevacizumab) has been shown to increase VM in ovarian and breast cancer [21, 22]. Anti-VM therapies have had limited success, with currently only one drug, CVM-1118 (NCT03582618), in Phase 2 open label clinical trial $[23,24]$. Hence, understanding the mechanisms involved in VM formation is clearly clinically important.

CD36 is an $88 \mathrm{kDa}$ cell surface glycoprotein well documented as a scavenger receptor on many cell types, including platelets, phagocytic cells, adipocytes, erythrocytes, specialized epithelia, myocytes and microvascular endothelium (reviewed in [25]). The functional diversity of CD36 is underpinned by its binding to distinct ligands including long chain fatty acids, phospholipids, oxidized low-density lipoprotein (oxLDL), amyloid proteins, advanced glycation end products and thrombospondin (TSP) [25]. In tumor tissues, CD36 is expressed by cancer cells, ECs, stromal cells and immune cells [26] with numerous studies supporting the notion that CD36 participates in the progression of cancer [27-29]. More specifically, retrospective analyses suggest that elevated levels of CD36 correlate with poor prognosis in patients with glioma, cervical cancer, ovarian cancer, lung cancer, squamous-cell carcinoma, bladder cancer, and luminal A breast cancer [27-30]. Consistent with this, overexpression studies have shown CD36 to increase the migration and invasion of cervical cancer cells in vitro, and its knockdown inhibited their metastatic potential [30]. Pascual and colleagues further demonstrated that short hairpin RNA-mediated depletion of CD36 significantly reduced metastases in models of melanoma (501mel) and breast cancer (MCF-7) in vivo [29]. Hypoxia is a well-known initiator of tumor vascularization and hypoxia has also been documented to elevate CD36 expression on microvascular ECs (MVECs) [31]. Taken together, these findings begin to reveal an important inter-relationship between cancer cells, tumor ECs and CD36. Interestingly, the CD36 ligand TSP-1 has been identified as a potent inhibitor of angiogenesis as it renders ECs non-responsive to proangiogenic stimuli such as vascular endothelial growth factor (VEGF) via changes in intracellular signaling pathways [32, 33] and its promotion of apoptosis [34]. Elevated levels of TSP-1 have indicated some suppressive control of tumor growth and cancer metastasis [35], likely via inhibition of tumor vasculature.

On the whole, the expression of CD36 has poor implications in cancer, and while CD36 has gained significant attention in recent years, its role in tumor vasculature and cancer progression is still not fully understood. The aim of the present study is to investigate the currently unknown role of CD36 in VM by melanoma cells.

\section{Methods \\ Bioinformatics analysis of publicly available datasets \\ To analyze The Cancer Genome Atlas (TCGA) data, RNA sequencing (RNA-seqV2) and clinical (Biotab) data were downloaded from the Data Portal at http:// cancergenome.nih.gov/. Data were analyzed in Biocon- ductor, using the edgeR package to perform differential gene expression analysis. A Kaplan Meier plot was gen- erated to compare the overall survival between patients expressing the top $10 \%$ of $C D 36$ against the patients ex- pressing the bottom $10 \%$ of CD36.}

\section{Cell culture}

Human melanoma cell lines C32 and SK-MEL-28 were gifted from G McArthur (Peter MacCallum Cancer Centre, Melbourne, Vic, AUS) and cultured in RPMI 1640 (Gibco by Life Technologies, California, USA) 
containing $10 \%$ fetal bovine serum (FBS) (Hyclone, GE Healthcare Sciences, Utah, USA) and 1\% Glutamax 1x (Gibco) and cultured under standard conditions $\left(37^{\circ} \mathrm{C}\right.$, $\left.5 \% \mathrm{CO}_{2}\right)$. The isolation of endothelial colony-forming cells (ECFCs) from healthy human peripheral blood, as previously described [36], was approved by the human ethics committees of the University of South Australia (UniSA HREC \#201187). Briefly, collagen I-coated plates were seeded with lymphoprep enriched mononuclear cells and cultured in EGM-2 media (Lonza) containing 20\% Embryonic Stem cell screened fetal bovine serum (Hyclone, GE Healthcare, Chicago, IL, USA) until colony formation at $\sim 14$ days culture after which time the cells were passaged and cultured for no more than 9 passages. Human lung microvascular endothelial cells (HMVEC) were purchased from the Lonza (Basel, Switzerland) and cultured in Lonza EBM-2 basal medium to low passage number.

\section{Flow cytometry}

To determine cell surface expression of CD36, cells were labelled with anti-human CD36 antibody (FA6-152, Stem Cell Technologies, Vancouver, Canada) or isotype control $\left(\operatorname{IgG}_{1} \quad \mathrm{~K}\right)$ at a concentration of $10 \mu \mathrm{g} / \mathrm{ml}$ in RPMI1640 media (Sigma-Aldrich, Merck, Sydney Australia) containing 10\% FBS. Cells were then washed and stained with a secondary antibody, goat anti-mouse IgG H\&L Dylight 650 (Clone ab96882, Abcam, Cambridge, United Kingdom) at a concentration of $5 \mu \mathrm{g} / \mathrm{ml}$. Similarly, cells were labelled with directly conjugated antibodies within panels containing one or more of the following; anti-CD144 (VE-cadherin)-FITC, antiCD31(PECAM)-PE, anti-Tie-2-Alexa Fluor 647, antiCD146 (MCAM)-PE (all BD Bioscience) and anti-CD309 (VEGFR2)-Alexa Fluor 647 (Biolegend), with nonspecific isotype control antibodies, IgG1-FITC, IgG1-PE and IgG1-Alexa Fluor 647 (all BD Bioscience). Cell viability was determined via 7AAD (BD Biosciences) staining at a 1:20 dilution. Samples were processed using a BD Accuri C6 flow cytometer (BD, Becton, Dickinson and Company, New Jersey, USA) and data analyzed using FCS Express 4 Flow Research Edition (De Novo software, Los Angeles, USA).

\section{CD36 knockdown using siRNA}

CD36 targeting small interfering RNAs (siRNAs) Trilencer-27 Human siRNA duplexes at $20 \mu \mathrm{M}$ were purchased (Origene, Maryland, USA) with three CD36 targeting siRNAs (duplex sequences: SR319610A rCrArArCrCrUrArUrUrGrGrUrCrArArGrCrCrArUrCrArGAA, SR319610B rGrGrCrCrUrGrArUrArGrArArArUrGrArUr CrUrUrArCrUCA and SR319610C rGrGrArUrUrArArAr CrCrCrArArArUrGrArArGrArArGrAAC) plus a nontargeting scrambled (SCR) siRNA used as a negative control. Transfection was performed using Lipofectamine RNAiMAX (Invitrogen by Life Technologies, California, USA) as per the manufacturer's instructions with the knockdown maximized at $5 \mathrm{nM}$ and validated by flow cytometry.

\section{Vasculogenic mimicry (VM) assays}

VM assays were performed on Geltrex LDEV-Free Reduced Growth Factor Basement Membrane Matrix (Life Technologies, California, USA) with $10 \mu \mathrm{l}$ coating each of a 15 well $\mu$-Angiogenesis culture slides (Ibidi, Martinsreid, Germany) and allowed to solidify over $30 \mathrm{~min}$ at $37^{\circ} \mathrm{C}$. Human melanoma cancer cells were then seeded at $2 \times 10^{4}$ cells/well for C32 cells and $5 \times 10^{3}$ cells/well for SK-MEL-28 cells and after $6 \mathrm{~h}$ incubation at $37^{\circ} \mathrm{C}$, images of each well were obtained using the EVOS XL Core Imaging System (Thermo Fisher Scientific) with brightness of the images adjusted equally across groups to enhance image contrast for ease of readers. VM structures were defined as multi-cellular arrangements forming vessel-like structures from one branch point to another [16] and VM in each well was counted in blinded manner. A minimum of three independent experiments were performed. Similar experiments included cells without or with CD36-targeting siRNA knockdown or those pre-treated with TSP-1 (150 or $1500 \mathrm{ng} / \mathrm{ml})$, an anti-CD36 blocking antibody $(10 \mu \mathrm{g} /$ $\mathrm{ml}, \mathrm{FA6}-152)$ or an isotype control $\left(\mathrm{IgG}_{1}\right)$ for $30 \mathrm{~min}$ at $4{ }^{\circ} \mathrm{C}$ prior to seeding.

\section{Angiogenesis assays}

Human lung microvascular endothelial cells (HMVEC) were serum starved overnight in EBM-2 basal medium (Lonza, Basel, Switzerland) at $37^{\circ} \mathrm{C}$ prior to seeding onto Geltrex at a concentration of $2 \times 10^{4}$ cells/well within a 15 well $\mu$-Angiogenesis slide with or without the addition of TSP-1 (1500 ng/ml) in EBM-2 basal medium containing EGM-2 MV SingleQuot Kit supplements and growth factors (Lonza, Basel, Switzerland). After $6 \mathrm{~h}$, images of the angiogenesis formation were obtained using the EVOS XL Cell Imaging System. Angiogenesis formation was determined by blindly counting the vessel-like structures formed within each well with the use of ImageJ software.

\section{MTS survival assay}

HMVEC were seeded into 96-well flat bottom plates at a concentration of $2 \times 10^{4}$ cells/well in EBM-2 basal medium containing EGM-2 MV SingleQuot Kit supplements and growth factors. Cells were incubated at $37^{\circ} \mathrm{C}$ for $5 \mathrm{~h}$, washed in $1 \mathrm{x}$ PBS, serum starved in EBM-2 basal medium overnight at $37^{\circ} \mathrm{C}$ and then treated without or with TSP-1 (1500 ng/ml) for $6 \mathrm{~h}$ and $24 \mathrm{~h}$ at $37^{\circ} \mathrm{C}$. MTS (3-(4,5-dimethylthiazol-2-yl)-5(3-carboxymethoxyphenyl)-2-(4-sulfophenyl)-2H-tetrazolium; 
Life Technologies, California, USA) was then added to each well at a concentration of $0.5 \mathrm{mg} / \mathrm{ml}$ for $2 \mathrm{~h}$ at $37^{\circ} \mathrm{C}$. Viable cell density was determined by measuring absorbance at 490 $\mathrm{nm}$ on the Epoch microplate spectrophotometer (Biotek, USA).

\section{Inverse invasion assays}

Using previously described methods [37], growth factorreduced Matrigel diluted 1:1 in cold PBS was loaded into Transwells (Corning Inc., NY, USA) to set prior to being inverted and C32 cells $\left(2 \times 10^{5} / \mathrm{ml} \pm\right.$ CD36 knockdown via siRNA) were seeded onto the underside of the membrane. After four hours, the unbound cells were washed away and Transwells immersed right-way up in serumfree HUVEC media $\pm 10 \%$ FBS to the upper chamber and cells allowed to migrate upward into the Matrigel for two days. Transwells were fixed with paraformaldehyde for $30 \mathrm{~min}$, washed with PBS, RNAse-treated $(100 \mu \mathrm{g} / \mathrm{ml}$, Thermo Fisher) for $30 \mathrm{~min}$, washed with PBS, and stained with propidium iodide $(0.05 \mathrm{mg} / \mathrm{ml}$, Thermo Fisher). Starting at the membrane, Transwells were imaged at $10 \mu \mathrm{m}$ fixed intervals in a direction towards the chemoattractant using Zeiss LSM 700 confocal microscope with a 20x objective and z-stack setting (Carl Zeiss AG, Oberkochen, Germany). From three fields of view per slice, images were quantified using Image J software, through threshold adjustment and counting particles (cells), these were then averaged.

\section{Adhesion assays}

C32 melanoma cells $\left(1.5 \times 10^{4}\right.$ cells $)$ were seeded into wells of a flat bottom 96-well plate preloaded overnight at $4{ }^{\circ} \mathrm{C}$ with $10-50 \mu \mathrm{g} / \mathrm{ml}$ collagen I (Becton, Dickinson and Company, New Jersey, USA), collagen IV (Sigma-Aldrich, Missouri, United States), laminin (Roche, Basel, Switzerland), fibronectin (Roche, Basel, Switzerland) or Geltrex. Cells that had undergone a 72-h CD36targeting siRNA knockdown were harvested and resuspended in $1 \mathrm{mg} / \mathrm{ml}$ of bovine serum albumin (BSA) (Sigma Aldrich, Missouri, USA) in RPMI 1640 and seeded into the extracellular matrix (ECM) component containing wells and incubated at $37^{\circ} \mathrm{C}$ for $90 \mathrm{~min}$. Rose Bengal (Sigma Aldrich, Missouri, USA) diluted in warm $1 \mathrm{x}$ PBS to a concentration of $0.05 \%$, was then added to the cells for $10 \mathrm{~min}$ at RT prior to several washes with PBS. A 1:1 solution of methanol and PBS was then added to the cells for $10 \mathrm{~min}$ prior to the absorbance reading via spectrophotometry at $562 \mathrm{~nm}$ FLUOstar Omega plate reader (BMG LABTECH GmbH, Offenberg Germany).

Functional blocking studies using the mouse antiintegrin- $\alpha_{3}$ mAb (Clone P1B5; Sigma Aldrich, Missouri, USA) were performed by pre-incubating C32 melanoma cells at $37{ }^{\circ} \mathrm{C}$ with anti-integrin- $\alpha_{3} \mathrm{mAb}$ at $50 \mu \mathrm{g} / \mathrm{mL}$ for
30 min prior to cell attachment to wells coated with human laminin at $50 \mu \mathrm{g} / \mathrm{ml}$ as described above. Images of each well were obtained using the EVOS XL Core Imaging System.

\section{Immunocytochemistry}

Circular glass coverslips (Menzel Glaser, Germany) were placed into a 24-well plate (Nunc) and coated overnight at $4{ }^{\circ} \mathrm{C}$ with EHS-derived mouse laminin (Roche) at $20 \mu \mathrm{g} / \mathrm{mL}$ in PBS. C32 melanoma cells were harvested and resuspended in RPMI 1640 medium containing BSA at $1 \mathrm{mg} / \mathrm{mL}$; cells $\left(5 \times 10^{4}\right.$ per well) were allowed to adhere and spread for $60 \mathrm{~min}$ at $37^{\circ} \mathrm{C}$, and nonadherent cells removed by gentle washing. Cells were then fixed with $4 \%$ paraformaldehyde/PBS for $10 \mathrm{~min}$ at room temperature. After washing with PBS, cells were permeated with $0.25 \%$ Triton X-100 (Sigma-Aldrich) in PBS for $10 \mathrm{~min}$. Non-specific binding sites were blocked for 90 min using 3\% BSA in PBS containing a 1:10 dilution of nonimmune goat serum. Cells were incubated overnight at $4{ }^{\circ} \mathrm{C}$ with the primary antibodies [mouse antihuman integrin- $\alpha_{3}$ at $1 \mu \mathrm{g} / \mathrm{mL}$ (clone P1B5, Merck Australia); rabbit anti-human paxillin at $0.5 \mu \mathrm{g} / \mathrm{mL}$ (sc5574, Santa Cruz Biotechnology), mouse IgG1 isotype control at $1 \mu \mathrm{g} / \mathrm{mL}$ (BD Bioscience); and purified rabbit IgG at $0.5 \mu \mathrm{g} / \mathrm{mL}$ (Sigma-Aldrich)] in PBS containing $\mathrm{BSA}$ at $1 \mathrm{mg} / \mathrm{mL}$ and then counterstained with a $1: 1000$ dilution of Alexa Fluor 488-conjugated goat anti-rabbit and Alexa Fluor 555-conjugated goat anti-mouse IgG (Life Technologies) as well as a 1:3000 dilution of DAPI nuclear stain (Sigma-Aldrich) in PBS containing $1 \mathrm{mg}$ / $\mathrm{mL}$ BSA. Coverslips were mounted onto glass slides using Fluoromount (Sigma-Aldrich), and images were captured using a 63x objective fluorescence confocal photomicroscope (LSM800, Carl Zeiss Microscopy, Jena, Germany).

\section{Statistical analysis}

GraphPad PRISM software (San Diego, CA, USA) was used to perform statistical analyses and significance via a Mann Whitney $U$ test or one-way ANOVA. In all comparisons, $p<0.05$ was considered statistically significant.

\section{Results}

High CD36 gene expression suggests poor clinical outcome for patients with melanoma

Data obtained from The Cancer Genome Atlas (TCGA) was used to determine the significance of CD36 gene expression in the survival of patients with melanoma (TCGA-SKCM project, $n=470$ ). Patient data was categorized into samples within the top $10 \%$ of CD36 gene expression (CD36-high, $\mathrm{n}=47$ ) and those within the bottom 10\% of CD36 gene expression (CD36-low, $\mathrm{n}=$ 47) (Fig. 1A). Analysis of these two cohorts showed a 


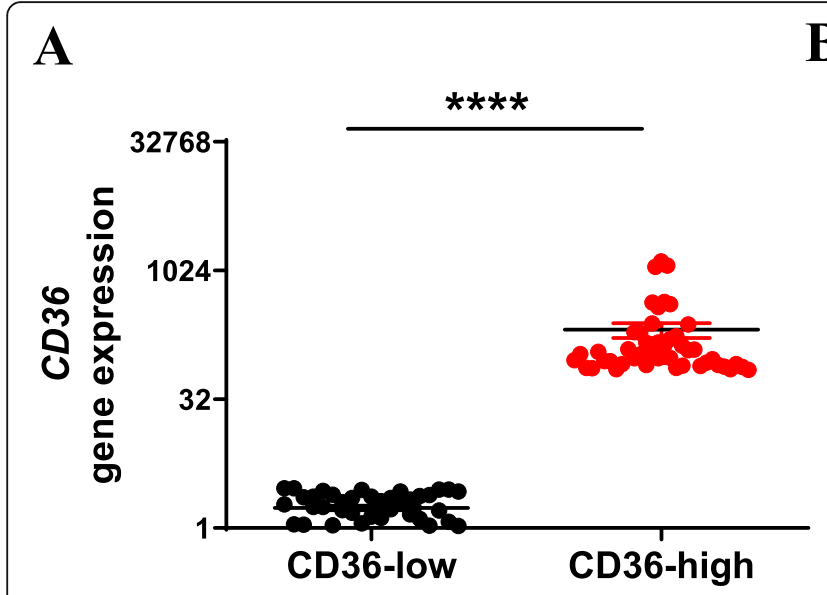

B

Fig. 1 Association of clinical outcome in melanoma patients with high CD36 expression. (A) Patient data accessed from the TCGA-SKCM project $(n=470)$ was categorized into the top and bottom 10\% of CD36 gene expression (CD36-high (red) and CD36-low (black), respectively), ${ }^{* * * *} p<$ 0.0001, unpaired t-test. (B) From the data in A, a Kaplan-Meier analysis was conducted between the CD36-high and CD36-low populations ( $n=47$ per group)

clear trend of decreased overall survival in patients who have high CD36 gene expression, compared to those with low CD36 expression, although this difference was not statistically significant (Fig. 1B).

\section{Melanoma cells perform vasculogenic mimicry which is, in part, mediated by $\mathrm{CD} 36$}

To determine whether CD36 expression contributes to $\mathrm{VM}$ in melanoma, in vitro VM assays were performed using two human melanoma cells lines, C32 and SKMEL-28 without and with CD36 knockdown. Figure 2A and E confirm the VM capability of both C32 and SKMEL-28 cell lines in vitro with Fig. $2 \mathrm{~B}$ and $\mathrm{F}$ demonstrating the ability of three different CD36-targeting siRNA constructs to consistently knockdown CD36 protein expression with an efficacy of up to $90 \%$. Having first confirmed that knockdown of CD36 did not compromise the viability of the cells (Fig. $2 \mathrm{C}$ and G), we went on to examine the contribution of CD36 to VM formation. After $72 \mathrm{~h}$ of CD36 knockdown, VM formation was significantly decreased in both the C32 (Fig. 2D and E) and SK-MEL-28 (Fig. 2H and I) cell lines, resulting in fragmented networks.

To elaborate on the potential vascular profile of the C32 and SK-Mel-28 melanoma cells, flow cytometric analysis was used to determine the expression of endothelial cell (EC) surface antigens VE-cadherin (CD144), PECAM (CD31), VEGFR2 (CD309), Tie-2 (CD202b) and MCAM (CD146). Figure 3 shows the surface expression of VE-cadherin on ECs but not on either of the melanoma cell lines. Interestingly, surface expression of PECA $M$ was identifiable on ECs and SK-Mel-28 cells, but not the C32 cells; while VEGFR2, Tie-2 and MCAM were identified on all three cell types.

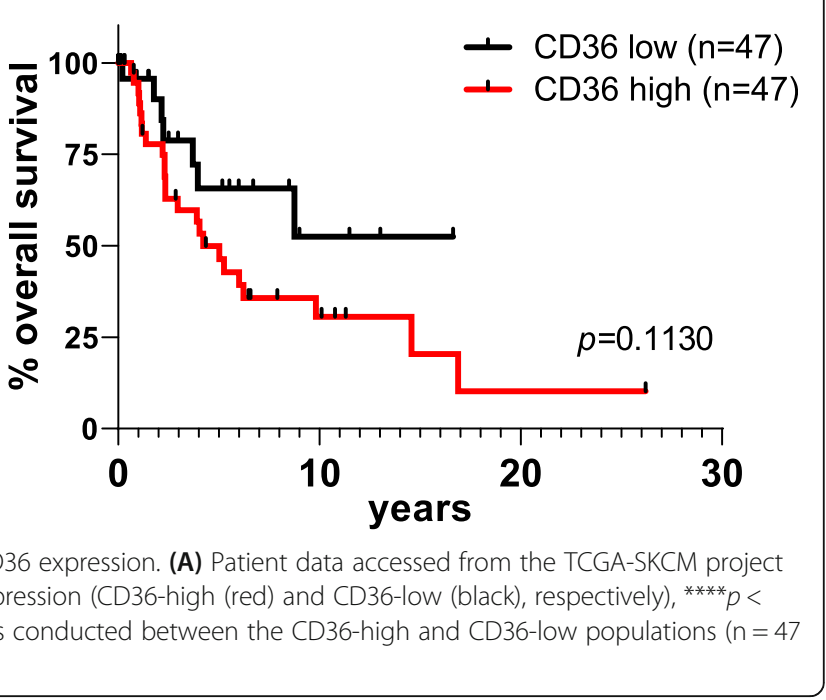

Exogenous TSP-1 does not inhibit VM capacity of melanoma cells

To investigate whether TSP-1, a known inhibitor of angiogenesis [32, 33] and a well-documented ligand for CD36, could also interfere with VM formation by CD36expressing melanoma cells. In vitro, we performed VM assays with the C32 melanoma cells in the presence of increasing concentrations of TSP-1. Based on the literature of circulating TSP-1 in patient plasma ranging from 245 $\mathrm{ng} / \mathrm{ml}$, in healthy individuals, to $3650 \mathrm{ng} / \mathrm{ml}$, in cancer patients [38], we included 0,150 and $1500 \mathrm{ng} / \mathrm{ml}$ of TSP-1 into the VM assays. Figure 4A illustrates that the VM structures were not perturbed by the increasing concentrations of TSP-1. Further support for TSP-1 not being the relevant ligand for $\mathrm{CD} 36$ in VM comes from our inclusion of the anti-CD36 blocking antibody (FA6-152) that specifically blocks CD36 binding to TSP-1 and collagen [39-41]. Figure 4B shows that addition of this anti-CD36 blocking antibody $(10 \mu \mathrm{g} / \mathrm{ml})$ did not inhibit VM formation, thus suggesting that neither TSP-1 nor CD36-engaged collagen are involved in VM formation by melanoma cancer cells.

Importantly, to confirm that our TSP-1 was indeed functional, we used the CD36 expressing human microvascular endothelial cells (HMVECs, Fig. 4C) in an angiogenesis assay [32, 33]. First, we confirmed that exposure of $1500 \mathrm{ng} / \mathrm{ml}$ of TSP-1 for up to $24 \mathrm{~h}$ did not compromise cell viability (Fig. 4C), prior to addition of TSP-1 into the angiogenesis assay which showed a significant reduction in angiogenesis by the HMVECs when TSP-1 was present (Fig. 4D). This differential between EC angiogenesis and cancer cell VM has not been reported previously and goes some way to describing the important differences between these two-contributing process of tumor vascularization. 


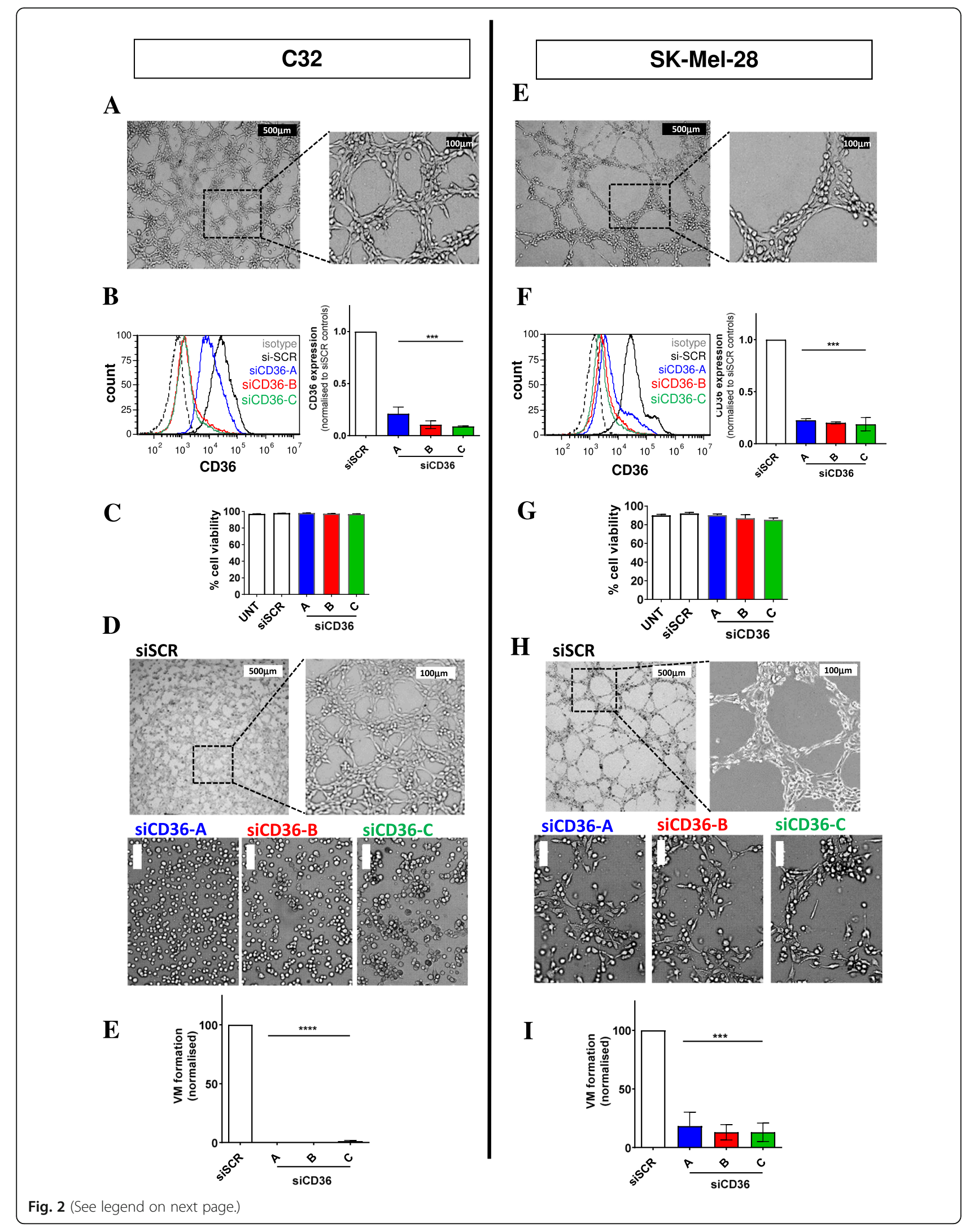


(See figure on previous page.)

Fig. 2 CD36 inhibition by siRNA attenuates VM by melanoma cells in vitro. (A, E) Representative images of C32 and SK-Mel-28 human melanoma cells undergoing VM. For each cell line, the left image depicts VM with low magnification (scale bar $=500 \mu \mathrm{m}$ ) and the right image is a zoomed in view of the same well using higher magnification (scale bar $=100 \mu \mathrm{m}$ ). (B, F) Left panels, flow cytometric histograms of CD36 expression on C32 and SK-Mel28 cells with isotype control (dotted line), CD36 (solid black line), and siCD36 knockdown cells (A, blue line; B, red line and C, green line). Right panels, bar graphs of flow data quantified from experimental repeats, siCD36 (constructs A-C) normalized to scrambled siRNA (siSCR) controls. Data are expressed as mean \pm SEM from $n=3$ experiments. ${ }^{* * *} p<0.001$ vs siSCR control, one-way ANOVA. (C, G) Cell viability without and with CD36 knockdown. Data are expressed as mean \pm SEM from $n=3$ experiments. (D, H) Top panels are representative images of C32 and SK-Mel-28 melanoma cells undergoing VM without or with siCD36 knockdown. For each cell line, the left image depicts VM with low magnification (scale bar $=500 \mu \mathrm{m})$ and the right image is a zoomed in view of the same well using higher magnification (scale bar $=100 \mu \mathrm{m}$ ). Lower panels illustrate the VM formation following CD36 knockdown for constructs RNAi A-C. (scale bar $=100 \mu \mathrm{m})(\mathbf{E}$, I) Quantitation of VM formation by the cancer cells, normalized to si-SCR control within each experiment. Data are expressed as mean \pm SEM from $n=3$ experiments. ${ }^{* * *} p<0.001$ vs si-SCR control, one-way ANOVA
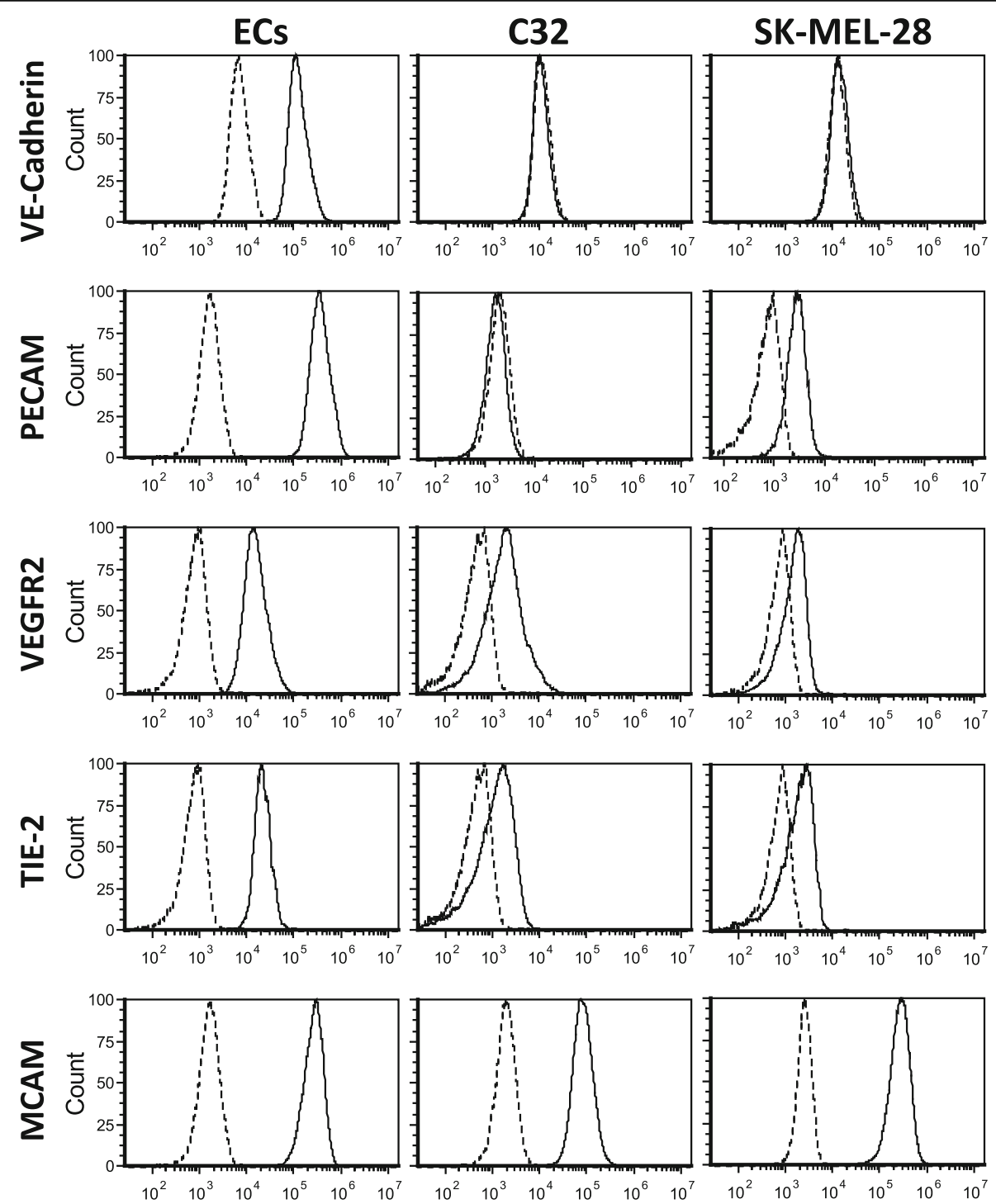

Fig. 3 Surface expression profiling of ECs, C32 and SK-Mel-28 cells. The histograms show one representative experiment from $n \geq 3$ replicates for each of the cell types with the dotted lines identifying isotype control stained cells and the solid lines representing cells stained for VE-cadherin, PECAM, VEGFR2, Tie-2 or MCAM 
A
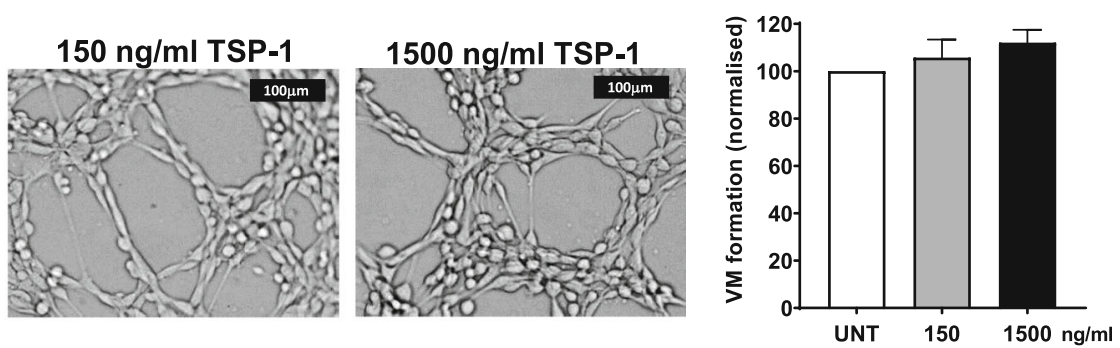

B
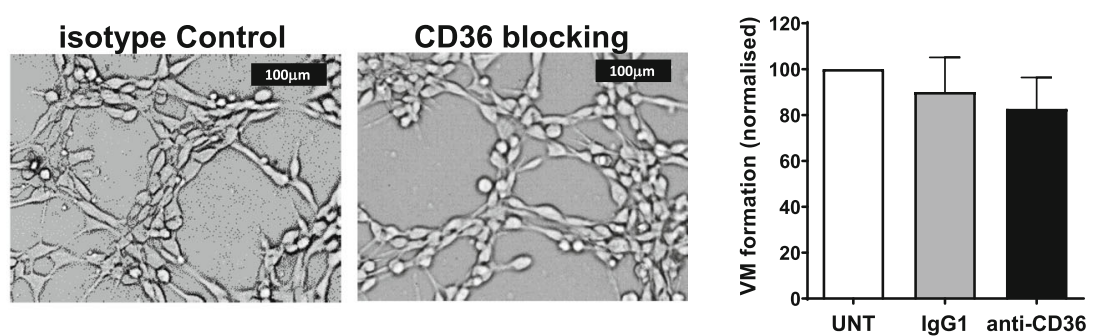

C
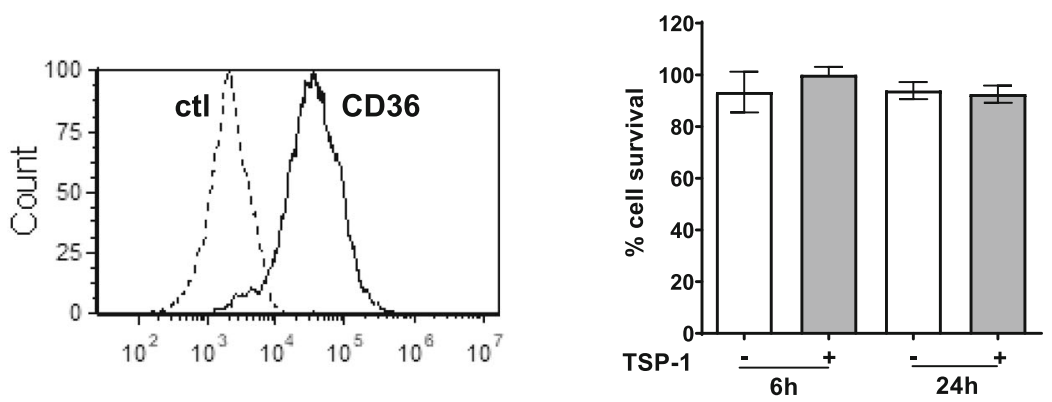

D
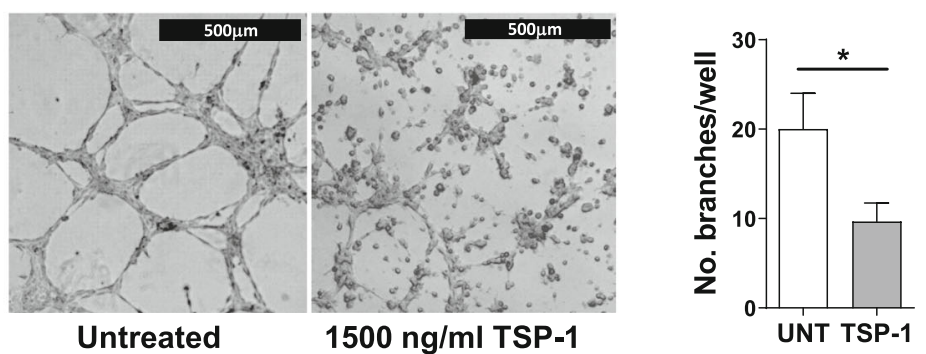

Fig. 4 Blocking CD36:TSP-1 interactions does not inhibit VM by melanoma cells. (A) VM formation by C32 melanoma cells assessed following treatment with 150 and $1500 \mathrm{ng} / \mathrm{ml}$ TSP-1. Microscopy images are representative of VM with TSP-1 treatments (scale bar $=100 \mu \mathrm{m}$ ). Right bar graph, number of VM normalized to untreated (UNT) controls. Data are mean \pm SEM from $n=3$ experiments. (B) VM formation by C32 melanoma cells assessed following administration of anti-CD36 mAb $(10 \mu \mathrm{g} / \mathrm{ml})$ or isotype $\mathrm{lgG} 1$ control $(10 \mu \mathrm{g} / \mathrm{ml})$ prior to cell seeding for VM assay. Microscopy images are representative of VM (scale bar $=100 \mu \mathrm{m})$. Right bar graph, number of VM normalized to untreated (UNT) controls. Data are mean \pm SEM from $n=3$ experiments. (C) Left histogram, flow cytometric analysis of CD36 expression on HMVEC cells with isotype control (dotted line) and CD36 (solid line). Right bar graph, survival of HMVECs assessed without or with $1500 \mathrm{ng} / \mathrm{ml}$ TSP-1 for $6 \mathrm{~h}$. Data are mean \pm SEM from $n=3$ experiments. (D) HMVEC angiogenesis without and with $1500 \mathrm{ng} / \mathrm{ml}$ TSP-1. Microscopy images are representative of EC angiogenesis (scale bar $=500 \mu \mathrm{m}$ ). Right bar graph is number of EC branches per well normalized to untreated (UNT) controls. Data are mean \pm SEM from $n=3$ experiments. ${ }^{*} p<0.05$, t-test

\section{CD36 receptor mediates melanoma cell adhesion to extracellular matrix components}

To further investigate the role of CD36 on VMcompetent melanoma cells, we performed inverse invasion assays wherein we tested the ability of C32 melanoma cells (without or with CD36) to crawl through an extracellular matrix (Matrigel) towards a chemoattractant (10\% FBS). Figure 5A shows that over $48 \mathrm{~h}$, the cells travelled between 50 and $150 \mu \mathrm{m}$ from the Transwell membrane with the majority 

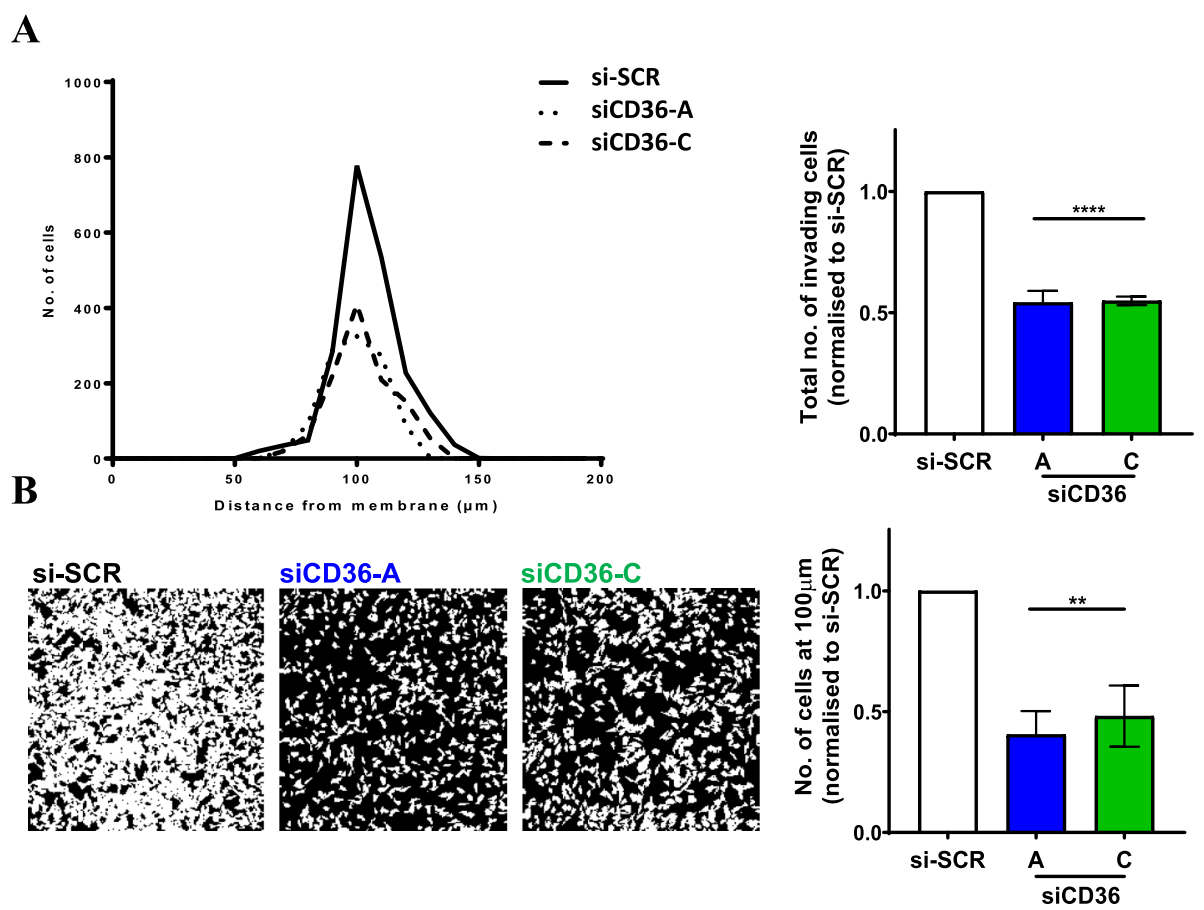

Fig. 5 CD36 facilitates the migration of melanoma cells. (A) Left panel, quantitated data of the distance travelled by C32 melanoma cells towards $10 \%$ FBS with siCD36 (siRNA A or C) or siRNA control (Scrambled). Right panel, quantitated data of total number of invading cells normalized to control (si-SCR). Data are mean \pm SEM from $n=3$ experiments. ${ }^{* * *} p<0.0001$ vs si-SCR, one-way ANOVA. (B) Left confocal images are representatives taken at a distance of $100 \mu \mathrm{m}$ from the Transwell membrane start point for si-SCR control or siCD36 (A and C). Images were captured via a 20x objective on a Zeiss LSM 700 confocal microscope. Right panel, quantitated data of the number of cells at $100 \mu \mathrm{m}$ from the Transwell membrane start point. Data are mean \pm SEM from $n=3$ experiments. ${ }^{* *} p<0.01$ vs si-SCR, one-way ANOVA

travelling $100 \mu \mathrm{m}$ over that time. The loss of CD36 (via siRNA knockdown) did not impact on the cancer cells being able to invade up to $150 \mu \mathrm{m}$. However, we observed that loss of CD36 significantly inhibited the number of $\mathrm{C} 32$ cells that migrated towards the FBS (Fig. 5A). This difference is best exemplified in Fig. 5B which illustrates the number of cancer cells at precisely $100 \mu \mathrm{m}$ from the Transwell membrane start point. With CD36 knockdown, there is a $50 \%$ reduction in cancer cells at this position. This data implies that CD36 facilitates an interaction between cancer cells and the extracellular matrix, and from our results above, CD36 is unlikely to interact with TSP-1 or collagen.

\section{Melanoma cells utilize CD36 to bind to laminin substrata}

To further investigate how CD36 may be contributing to cancer cell invasion through the extracellular matrix components, adhesion assays were performed on Geltrex and a selection of components contained within Geltrex known to be bound by CD36, i.e. collagen I, collagen IV and laminin. Adhesion to fibronectin was also examined as a matrix component that does not engage CD36. Figure 6 shows that following knockdown of CD36, the C32 melanoma cells demonstrated reduced binding to
Geltrex; adding further support to our findings of reduced VM and invasion. While no changes in cell adhesion were observed for C32 cells exposed to collagen I, collagen IV or fibronectin, when CD36 was knocked down, reduced adhesion to laminin was observed for both CD36-targeting siRNA constructs (Fig. 6).

\section{Binding of melanoma cells to laminin is facilitated through integrin- $a_{3}$}

Given that Thorne et al previously demonstrated an association between CD36 and integrin- $\alpha_{3} \beta_{1}$ on melanoma cells [42], and that integrin- $\alpha_{3}$, but not CD36, binds laminin, we next examined whether blocking integrin- $\alpha_{3}$ might inhibit the adhesion of VMcompetent melanoma cells and laminin in vitro. First, flow cytometry confirmed the cell surface expression of integrin- $\alpha_{3}$ on the C32 melanoma cells (Fig. 7A). In support for integrin- $\alpha_{3}$ actively engaging with laminin, C32 cells were seeded on to laminin and immunocytochemistry identified active focal contacts at the cell periphery which contained both integrin- $\alpha_{3}$ and paxillin (Fig. 7B). Finally, we observed that C32 cell adhesion to laminin could be partly blocked via an anti-integrin- $\alpha_{3}$ blocking antibody (Fig. 7C). 

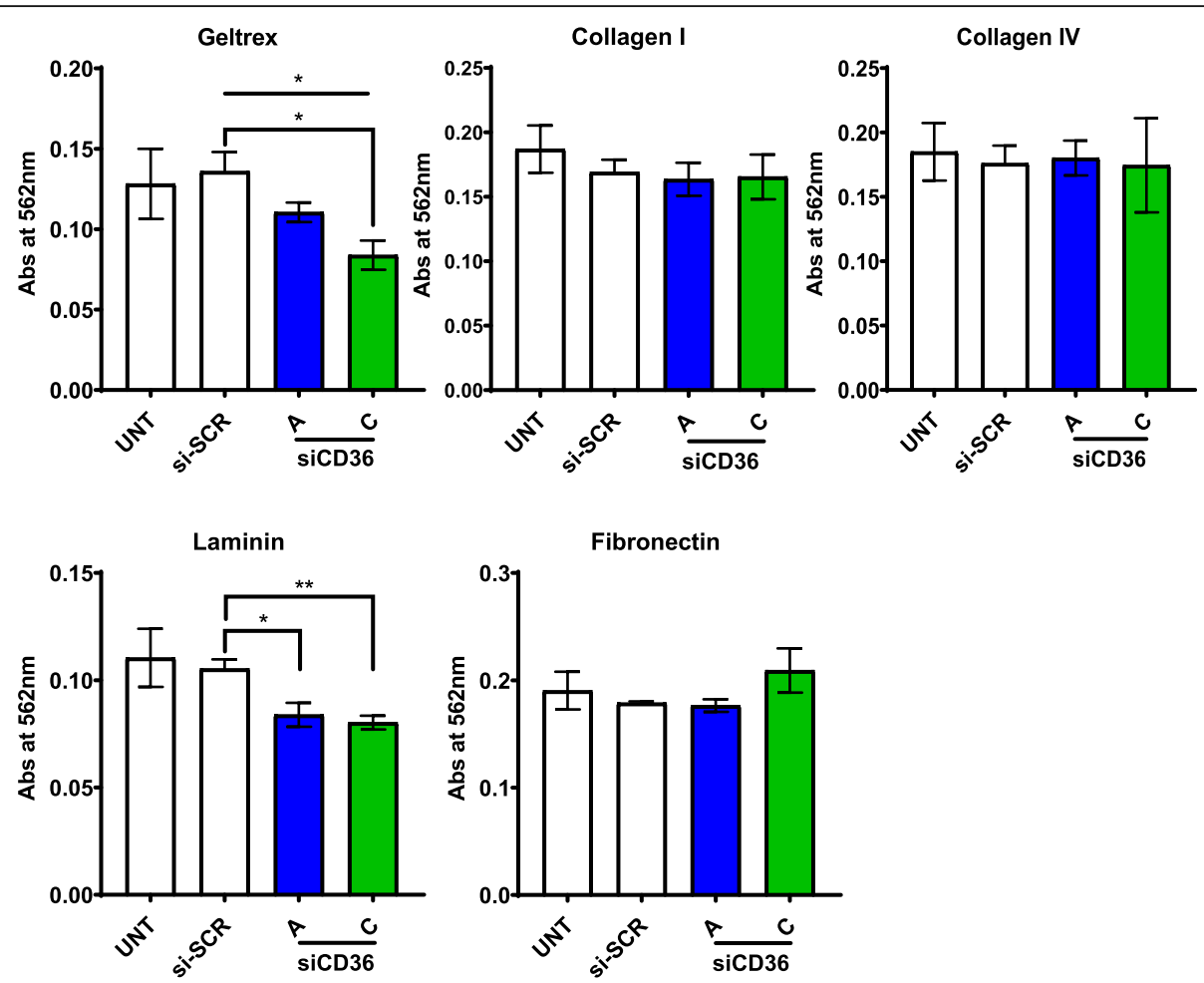

Fig. 6 CD36 aids selective adhesion by melanoma cells to components of the ECM. Rose Bengal staining of C32 melanoma cells, without and with siCD36 knockdown (untreated (UNT), siRNA control (si-SCR), and CD36-targeting siRNA (siCD36 A and C)) following 90 min exposure to plates coated with Geltrex, Collagen I, Collagen IV, Laminin or Fibronectin. Data are mean \pm SEM from $n=3$ experiments. ${ }^{*} p<0.05$, ${ }^{* *} p<0.01$, one-way ANOVA

\section{Discussion}

CD36, most widely known for its role as a scavenger receptor involved in the uptake of fatty acids, is gaining interest in the field of cancer research [29, 43, 44]. Expression of CD36 has been shown to correlate with poor prognosis (disease-free survival and overall survival) in luminal A breast cancer, lung squamous cell carcinoma, bladder cancer and melanoma $[29,45]$, with studies primarily focusing on the role of CD36 as a receptor for oxidized low density lipoprotein (oxLDL). Our own interrogation of the TCGA-SKCM database suggests that high expression of CD36 correlates with poor clinical outcome for patients with melanoma (albeit not significantly) and corroborates the study by Nath and Chan [45]; thus lending further weight to investigating CD36 in melanoma.

Here we reveal an unexpected role for CD36 in VM formation by melanoma cancer cells. More specifically, using the in vitro angiogenesis assay with two human melanoma VM-competent cell lines [16], we observed that knockdown of CD36 by siRNA significantly perturbed VM formation. To further examine the contribution of CD36 to VM formation, our invasion assays showed that in the absence of CD36 on melanoma cancer cells, their ability to migrate through an ECM was compromised, thus suggesting a direct interaction of CD36 with one or more components of the ECM. Interestingly, TSP-1, a known ligand of CD36 that inhibits angiogenesis by ECs [32, 46], was unable to inhibit VM formation by the cancer cells. Congruent with this, a CD36 blocking antibody (clone FA6-152) that specifically targets the epitopes for TSP-1 and collagen [39-41] also failed to prevent VM formation in our assays. Taken together, this data suggests that CD36-expressing VMcompetent cancer cells may utilize CD36 differently to ECs for the formation of vascular structures; a process that is yet to be fully elucidated. Transient knockdown of CD36 in melanoma cells did not influence cell viability but did compromise the number of cells that migrated, again suggesting a role for CD36 in cell adhesion. This supports recent studies wherein CD36 proved important for the migration and invasion of breast cancer cells and cervical cancer cells in vitro [30, 47]. More specifically, these studies show that CD36 can promote the activation of the MAPK signaling pathway, upregulate protein expression of $\mathrm{Bcl} 2$ and cyclin $\mathrm{D} 1$ and engage with the TGF- $\beta$ signaling for epithelial to mesenchymal transition (EMT) by cancer cells [30, 47].

To further elucidate the role for CD36 on cancer cells to engage with ECM components, adhesion assays were 


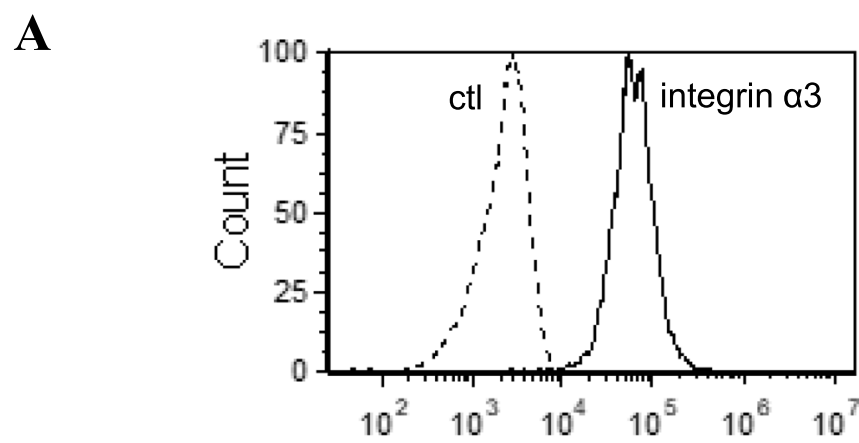

B
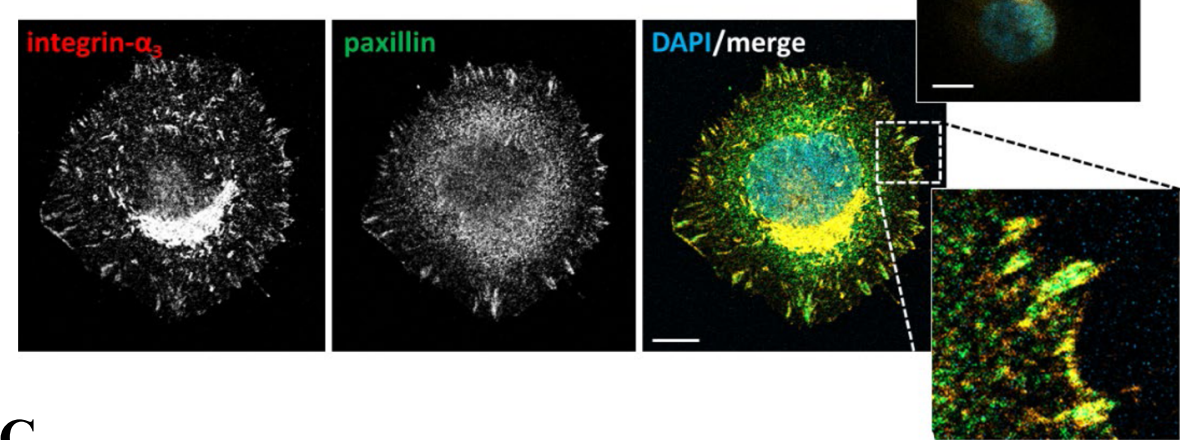

C
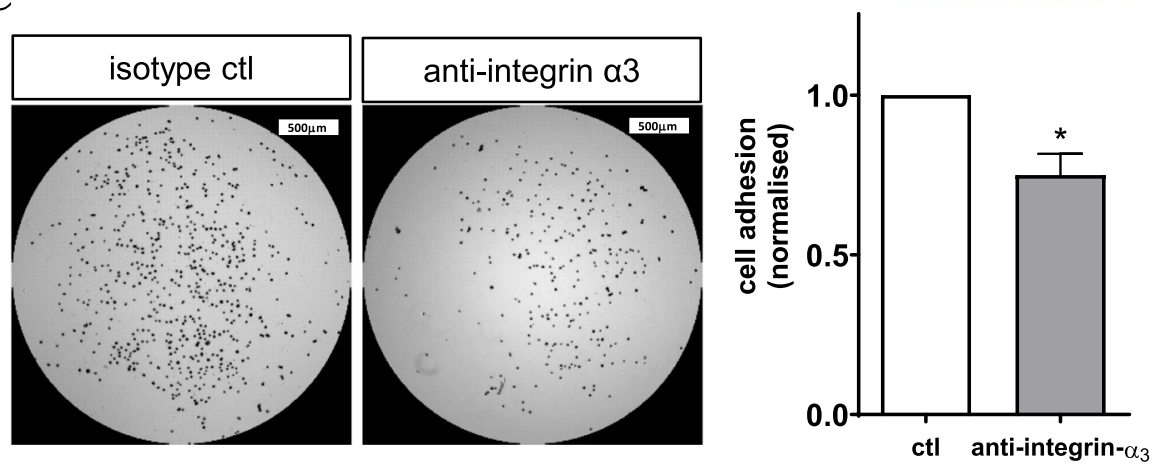

Fig. 7 Integrin- $a_{3}$ supports melanoma cell adhesion to laminin. (A) Flow cytometric analysis of integrin-a3 expression on C32 melanoma cells with isotype control (dotted line) and integrin-a3 (solid line). (B) Adhesion of C32 melanoma cells on to laminin coated coverslips for 60 min prior to staining for integrin- $a_{3}$ (left panel), paxillin (middle panel) and a nuclear stain (DAPI, colored merged image). Dual stained focal contacts shown in high magnification insert (bottom right). Isotype control stains shown in the top insert. Scale bar $=10 \mu \mathrm{m}$. (C) Adhesion of C32 melanoma cells treated with an anti-integrin-a3 antibody or isotype control onto tissue culture plates coated with $50 \mu \mathrm{g} / \mathrm{ml}$ laminin. Microscopy images (left) illustrate the density of adherent cells on each well surface. Scale bar $=500 \mu \mathrm{m}$. Bar graph (right), quantification of C32 melanoma cell adhesion to laminin as assessed following treatment with a blocking anti-integrin-a3 antibody or isotype control. Results are normalized to control (ctl) wells and are mean \pm SEM from $n=3$ experiments. ${ }^{*} p<0.05$, t-test

performed on collagen I, collagen IV, laminin and fibronectin, all of which are in high abundance in the ECM of tumors [48] and all are documented ligands for CD36 [42]. Here we observed that loss of CD36 significantly reduced the ability of melanoma cells to bind to the laminin substrata while retaining full binding capacity to collagen I, collagen IV and fibronectin. The retained binding to collagen is supported by our observations of the anti-CD36 monoclonal antibody (clone FA6-152
[39-41]) failing to inhibit VM formation by the cancer cells. Our observation of CD36-knockdown melanoma cells exhibiting reduced adhesion to laminin concurs with a study by Ladanyi and colleagues who demonstrated that ovarian cancer cells utilize CD36 for adhesion to laminin [27]. A potential mechanism by which this interaction may occur is via a lateral association with integrins, specifically the laminin binding integrins $\alpha_{3} \beta_{1}$ and $\alpha_{6} \beta_{1}[49,50]$ both of which have been reported 
to associate with CD36 in human melanoma cells for enhanced migration on ECM components [42]. Here we reveal that like CD36, blocking integrin- $\alpha_{3}$ on melanoma cells inhibited the binding of melanoma cells to laminin in vitro. Taken together, this study leads us to hypothesize that CD36 expression by melanoma cells modulates the function of integrins to promote shape change and migration on ECM components, thereby facilitating the formation of VM structures (Fig. 8).

Increasing literature demonstrates that overexpression of CD36 in cell lines of cervical and oral squamous cell carcinoma significantly increases their metastatic potential in vivo $[29,30]$. In accordance, CD36 neutralizing antibodies have been successfully used to combat metastasis in mouse models [29]. More specifically, repeated injections of the anti-CD36 antibody (clone FA6-152) significantly attenuated the metastasis of oral squamous cell carcinoma without effect on the primary tumor [29]. Whether these anti-CD36 treated tumors contained fewer VM structures was not determined.

Our in-silico analysis of the TCGA database supports our hypothesis that high expression of CD36 correlates with poor outcome for patients with melanoma. Whether CD36 could serve as a useful biomarker for personalized medicine is not known, but with clinical trials targeting CD36 for patients with metabolic disease $[43,51]$, an opportunity to repurpose an anti-CD36 molecule remains of interest. Notably, caution surrounding CD36 as a target to treat cancer is unsurprising given that it is a fatty acid scavenger receptor with a wide range of ligands. Indeed, lipotoxicity was observed in tumor bearing mice treated with the CD36-neutralising antibody [29]. Clearly, while the refinement of CD36targeting antibodies requires significant attention, there is increasing interest in CD36 as a potential prognostic for patients with colon, ovarian, breast, small cell lung carcinoma and urinary bladder cancer [29, 43, 44] and melanoma. This study adds to this interest by identifying a key role for CD36 in the lateral interactions with integrin- $\alpha_{3}$ to promote adhesion to the ECM (particularly laminin) to facilitate VM formation, an emerging process that contributes significantly to the progression of cancer (Fig. 8).

\section{Conclusions}

The results from this study identify CD36 as a previously unrecognized regulator of VM by melanoma cancer cells. The VM process is multifaceted and our

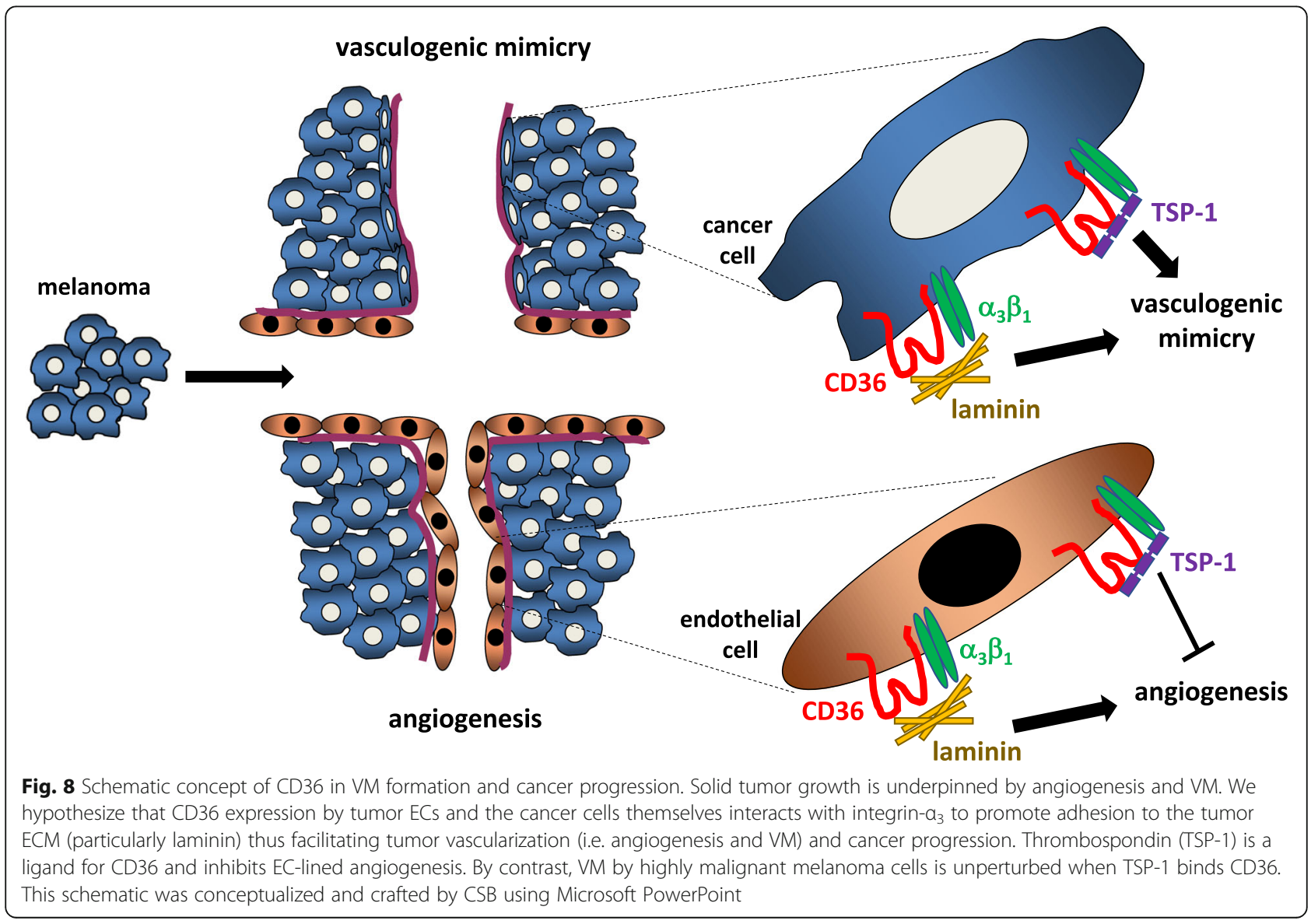


study suggests that CD36 contributes by co-operating with adhesion molecules (such as integrin- $\alpha_{3}$ ) to engage with components of the tumor microenvironment (such as laminin). Interestingly, our results suggest that VM differs from angiogenesis in that TSP-1 does not inhibit VM formation whereas it does perturb angiogenesis by ECs. This new information contributes to our understanding that both ECs and cancer cells form vascular structures within a tumor mass via processes that are not entirely identical. These differences will become important as we work towards specifically targeting tumor vascularization to best combat cancer progression.

\begin{abstract}
Abbreviations
EC: Endothelial cell; VM: Vasculogenic mimicry; TSP-1: Thrombospondin-1; VEcadherin: Vascular endothelial; EphA2: Ephrin receptor A2; PECAM-1: Platelet endothelial cellular adhesion molecule; PAS: Periodic acid-Schiff stain; MVECs: Microvascular ECs; FBS: Fetal bovine serum; siRNAs: small interfering RNAs; HMVEC: Human lung microvascular endothelial cells; BSA: Bovine serum albumin; ECM: Extracellular matrix; TCGA: The Cancer Genome Atlas; EMT: Epithelial to mesenchymal transition
\end{abstract}

\section{Acknowledgements}

The authors thank Samantha Escarbe for expert technical assistance and wish to acknowledge specimen donors and researchers within the TCGA Research Network.

\section{Authors' contributions}

Conceived and designed experiments: $C M, M D, B D, A E W, L M E$ and CSB. Performed experiments: CM, MD, DK, MPC and BE. Analyzed data: CM, MD, MPC and BE. Wrote manuscript: CM, LME, AEW and CSB. All authors have read and approved the manuscript.

\section{Funding}

This project was supported by primary research grants to CSB from the National Health and Medical Research Council of Australia (NHMRC, GNT1022150) and the Royal Adelaide Hospital (RAH) Research Foundation. LE was supported by an RAH Research Foundation Florey Fellowship. CM was supported by an Australian Postgraduate Award.

\section{Availability of data and materials}

The data analysed in this study are available in The Cancer Genome Atlas (TCGA) repository together with RNA sequencing (RNA-seqV2) and clinical (Biotab) data available from the Data Portal at http://cancergenome.nih.gov.

\section{Declarations}

Ethics approval and consent to participate

All cell lines were purchased from commercial sources or gifted as stated. No ethics approvals were required for this study.

\section{Consent for publication}

All authors have consented to the publication of this manuscript.

\section{Competing interests}

The authors declare no conflict of interest.

\section{Author details}

${ }^{1}$ Centre for Cancer Biology, University of South Australia and SA Pathology, Adelaide, South Australia, Australia. ${ }^{2}$ Clinical \& Health Sciences, University of South Australia, Adelaide, South Australia, Australia. ${ }^{3}$ Adelaide Medical School Faculty of Health and Medical Sciences, The University of Adelaide, Adelaide, South Australia, Australia.
Received: 29 December 2020 Accepted: 11 June 2021

Published online: 02 July 2021

\section{References}

1. El Hallani S, Boisselier B, Peglion F, Rousseau A, Colin C, Idbaih A, et al. A new alternative mechanism in glioblastoma vascularization: tubular vasculogenic mimicry. Brain. 2010;133(Pt 4):973-82. https://doi.org/10.1093/ brain/awq044.

2. Wang SY, Ke YQ, Lu GH, Song ZH, Yu L, Xiao S, et al. Vasculogenic mimicry is a prognostic factor for postoperative survival in patients with glioblastoma. J Neuro-Oncol. 2013;112(3):339-45. https://doi.org/10.1007/s11 060-013-1077-7.

3. Ricci-Vitiani L, Pallini R, Biffoni M, Todaro M, Invernici G, Cenci T, et al. Tumour vascularization via endothelial differentiation of glioblastoma stemlike cells. Nature. 2010;468(7325):824-8. https://doi.org/10.1038/nature09557.

4. Baeten Cl, Hillen F, Pauwels P, de Bruine AP, Baeten CG. Prognostic role of vasculogenic mimicry in colorectal cancer. Dis Colon Rectum. 2009:52(12): 2028-35. https://doi.org/10.1007/DCR.0b013e3181beb4ff.

5. Li W, Zong S, Shi Q, Li H, Xu J, Hou F. Hypoxia-induced vasculogenic mimicry formation in human colorectal cancer cells: involvement of HIF-1a, Claudin-4, and E-cadherin and vimentin. Sci Rep. 2016;6(1):37534. https:// doi.org/10.1038/srep37534.

6. Shirakawa K, Wakasugi H, Heike Y, Watanabe I, Yamada S, Saito K, et al. Vasculogenic mimicry and pseudo-comedo formation in breast cancer. Int J Cancer. 2002;99(6):821-8. https://doi.org/10.1002/ijc.10423.

7. Liu TJ, Sun BC, Zhao XL, Zhao XM, Sun T, Gu Q, et al. CD133+ cells with cancer stem cell characteristics associates with vasculogenic mimicry in triple-negative breast cancer. Oncogene. 2013;32(5):544-53. https://doi.org/1 0.1038/onc.2012.85.

8. Sood AK, Seftor EA, Fletcher MS, Gardner LM, Heidger PM, Buller RE, et al. Molecular determinants of ovarian cancer plasticity. Am J Pathol. 2001; 158(4):1279-88. https://doi.org/10.1016/50002-9440(10)64079-5.

9. Sood AK, Fletcher MS, Zahn CM, Gruman LM, Coffin JE, Seftor EA, et al. The clinical significance of tumor cell-lined vasculature in ovarian carcinoma: implications for anti-vasculogenic therapy. Cancer Biol Ther. 2002;1(6):661-4. https://doi.org/10.4161/cbt.316.

10. Zhuo M, Yuan C, Han T, Hu H, Cui J, Jiao F, et al. JQ1 effectively inhibits vasculogenic mimicry of pancreatic ductal adenocarcinoma cells via the ERK1/2-MMP-2/9 signaling pathway both in vitro and in vivo. Am J Transl Res. 2019;11(2):1030-9.

11. Sharma N, Seftor RE, Seftor EA, Gruman LM, Heidger PM Jr, Cohen MB, et al. Prostatic tumor cell plasticity involves cooperative interactions of distinct phenotypic subpopulations: role in vasculogenic mimicry. Prostate. 2002; 50(3):189-201. https://doi.org/10.1002/pros.10048.

12. Hendrix MJ, Seftor EA, Hess AR, Seftor RE. Vasculogenic mimicry and tumour-cell plasticity: lessons from melanoma. Nat Rev Cancer. 2003;3(6): 411-21. https://doi.org/10.1038/nrc1092.

13. Delgado-Bellido D, Serrano-Saenz S, Fernandez-Cortes M, Oliver FJ. Vasculogenic mimicry signaling revisited: focus on non-vascular VE-cadherin. Mol Cancer. 2017;16(1):65. https://doi.org/10.1186/s12943-017-0631-X.

14. Maniotis AJ, Folberg R, Hess A, Seftor EA, Gardner LM, Pe'er J, et al. Vascular channel formation by human melanoma cells in vivo and in vitro: vasculogenic mimicry. Am J Pathol. 1999;155(3):739-52. https://doi.org/10.1 016/S0002-9440(10)65173-5.

15. Folberg R, Hendrix MJ, Maniotis AJ. Vasculogenic mimicry and tumor angiogenesis. Am J Pathol. 2000;156(2):361-81. https://doi.org/10.1016/ S0002-9440(10)64739-6.

16. Tan LY, Mintoff C, Johan MZ, Ebert BW, Fedele C, Zhang YF, et al. Desmoglein 2 promotes vasculogenic mimicry in melanoma and is associated with poor clinical outcome. Oncotarget. 2016;7(29):46492-508. https://doi.org/10.18632/oncotarget.10216.

17. Folberg R, Maniotis AJ. Vasculogenic mimicry. APMIS. 2004;112(7-8):508-25. https://doi.org/10.1111/j.1600-0463.2004.apm11207-0810.x.

18. Shirakawa K, Kobayashi H, Heike Y, Kawamoto S, Brechbiel MW, Kasumi F, et al. Hemodynamics in vasculogenic mimicry and angiogenesis of inflammatory breast cancer xenograft. Cancer Res. 2002;62(2):560-6.

19. Yang JP, Liao YD, Mai DM, Xie P, Qiang YY, Zheng LS, et al. Tumor vasculogenic mimicry predicts poor prognosis in cancer patients: a metaanalysis. Angiogenesis. 2016;19(2):191-200. https://doi.org/10.1007/s10456016-9500-2. 
20. Cao Z, Bao M, Miele L, Sarkar FH, Wang Z, Zhou Q. Tumour vasculogenic mimicry is associated with poor prognosis of human cancer patients: a systemic review and meta-analysis. Eur J Cancer. 2013;49(18):3914-23. https://doi.org/10.1016/j.ejca.2013.07.148.

21. Sun H, Zhang D, Yao Z, Lin X, Liu J, Gu Q, et al. Anti-angiogenic treatment promotes triple-negative breast cancer invasion via vasculogenic mimicry. Cancer biology \& therapy. 2017;18(4):205-13. https://doi.org/10.1080/15384 047.2017.1294288

22. Xu Y, Li Q, Li XY, Yang QY, Xu WW, Liu GL. Short-term anti-vascular endothelial growth factor treatment elicits vasculogenic mimicry formation of tumors to accelerate metastasis. J Exp Clin Cancer Res. 2012;31(1):16. https://doi.org/10.1186/1756-9966-31-16

23. Hendrix MJ, Seftor EA, Seftor RE, Chao JT, Chien DS, Chu YW. Tumor cell vascular mimicry: novel targeting opportunity in melanoma. Pharmacol Ther. 2016;159:83-92. https://doi.org/10.1016/j.pharmthera.2016.01.006.

24. Fernandez-Cortes M, Delgado-Bellido D, Oliver FJ. Vasculogenic mimicry: become an endothelial cell "but not so much". Front Oncol. 2019;9:803. https://doi.org/10.3389/fonc.2019.00803.

25. Silverstein RL, Febbraio M. CD36, a scavenger receptor involved in immunity, metabolism, angiogenesis, and behavior. Sci Signal. 2009; 2(72):re3.

26. Wang J, Li Y. CD36 tango in cancer: signaling pathways and functions. Theranostics. 2019;9(17):4893-908. https://doi.org/10.7150/thno.36037.

27. Ladanyi A, Mukherjee A, Kenny HA, Johnson A, Mitra AK, Sundaresan S, et al. Adipocyte-induced CD36 expression drives ovarian cancer progression and metastasis. Oncogene. 2018;37(17):2285-301. https://doi.org/10.1038/s41388017-0093-z.

28. Hale JS, Otvos B, Sinyuk M, Alvarado AG, Hitomi M, Stoltz K, et al. Cancer stem cell-specific scavenger receptor CD36 drives glioblastoma progression. Stem Cells. 2014;32(7):1746-58. https://doi.org/10.1002/stem.1716.

29. Pascual G, Avgustinova A, Mejetta S, Martin M, Castellanos A, Attolini CS, et al. Targeting metastasis-initiating cells through the fatty acid receptor CD36. Nature. 2017:541(7635):41-5. https://doi.org/10.1038/nature20791.

30. Deng $M$, Cai X, Long L, Xie L, Ma H, Zhou Y, et al. CD36 promotes the epithelial-mesenchymal transition and metastasis in cervical cancer by interacting with TGF-beta. J Transl Med. 2019;17(1):352. https://doi.org/10.11 86/s12967-019-2098-6.

31. Mwaikambo BR, Yang C, Chemtob S, Hardy P. Hypoxia up-regulates CD36 expression and function via hypoxia-inducible factor-1- and phosphatidylinositol 3-kinase-dependent mechanisms. J Biol Chem. 2009; 284(39):26695-707. https://doi.org/10.1074/jbc.M109.033480.

32. Chu LY, Ramakrishnan DP, Silverstein RL. Thrombospondin-1 modulates VEGF signaling via CD36 by recruiting SHP-1 to VEGFR2 complex in microvascular endothelial cells. Blood. 2013;122(10):1822-32. https://doi. org/10.1182/blood-2013-01-482315.

33. Iruela-Arispe $\mathrm{ML}$, Lombardo $\mathrm{M}$, Krutzsch HC, Lawler J, Roberts DD. Inhibition of angiogenesis by thrombospondin-1 is mediated by 2 independent regions within the type 1 repeats. Circulation. 1999;100(13):1423-31. https:// doi.org/10.1161/01.CIR.100.13.1423.

34. Jimenez B, Volpert OV, Crawford SE, Febbraio M, Silverstein RL, Bouck N. Signals leading to apoptosis-dependent inhibition of neovascularization by thrombospondin-1. Nat Med. 2000;6(1):41-8. https://doi.org/10.1038/71517.

35. Tuszynski GP, Nicosia RF. The role of thrombospondin-1 in tumor progression and angiogenesis. Bioessays. 1996;18(1):71-6. https://doi.org/1 0.1002/bies.950180113

36. Martin-Ramirez J, Hofman M, van den Biggelaar M, Hebbel RP, Voorberg J. Establishment of outgrowth endothelial cells from peripheral blood. Nat Protoc. 2012;7(9):1709-15. https://doi.org/10.1 038/nprot.2012.093.

37. Hennigan RF, Hawker KL, Ozanne BW. Fos-transformation activates genes associated with invasion. Oncogene. 1994;9(12):3591-600

38. Tuszynski GP, Smith M, Rothman VL, Capuzzi DM, Joseph RR, Katz J, et al. Thrombospondin levels in patients with malignancy. Thromb Haemost. 1992;67(6):607-11.

39. Dawson DW, Pearce SF, Zhong R, Silverstein RL, Frazier WA, Bouck NP. CD36 mediates the in vitro inhibitory effects of thrombospondin-1 on endothelial cells. J Cell Biol. 1997;138(3):707-17. https://doi.org/10.1 083/jcb.138.3.707

40. Li Y, Qi X, Tong X, Wang S. Thrombospondin 1 activates the macrophage Toll-like receptor 4 pathway. Cell Mol Immunol. 2013;10(6):506-12. https:// doi.org/10.1038/cmi.2013.32.
41. Thelen T, Hao Y, Medeiros Al, Curtis JL, Serezani CH, Kobzik L, et al. The class a scavenger receptor, macrophage receptor with collagenous structure, is the major phagocytic receptor for Clostridium sordellii expressed by human decidual macrophages. J Immunol. 2010;185(7):4328-35. https://doi.org/10.4 049/jimmunol.1000989.

42. Thorne RF, Marshall JF, Shafren DR, Gibson PG, Hart IR, Burns GF. The integrins alpha3beta1 and alpha6beta1 physically and functionally associate with CD36 in human melanoma cells. Requirement for the extracellular domain OF CD36. J Biol Chem. 2000;275(45):35264-75. https://doi.org/10.1 074/jbc.M003969200.

43. Enciu AM, Radu E, Popescu ID, Hinescu ME, Ceafalan LC. Targeting CD36 as biomarker for metastasis prognostic: how far from translation into clinical practice? Biomed Res Int. 2018;2018:7801202.

44. Rachidi SM, Qin T, Sun S, Zheng WJ, Li Z. Molecular profiling of multiple human cancers defines an inflammatory cancer-associated molecular pattern and uncovers KPNA2 as a uniform poor prognostic cancer marker. PLoS One. 2013;8(3):e57911. https://doi. org/10.1371/journal.pone.0057911.

45. Nath A, Chan C. Genetic alterations in fatty acid transport and metabolism genes are associated with metastatic progression and poor prognosis of human cancers. Sci Rep. 2016;6(1):18669. https:// doi.org/10.1038/srep18669.

46. Good DJ, Polverini PJ, Rastinejad F, Le Beau MM, Lemons RS, Frazier WA, et al. A tumor suppressor-dependent inhibitor of angiogenesis is immunologically and functionally indistinguishable from a fragment of thrombospondin. Proc Natl Acad Sci U S A. 1990;87(17):6624-8. https://doi. org/10.1073/pnas.87.17.6624.

47. Liang Y, Han H, Liu L, Duan Y, Yang X, Ma C, et al. CD36 plays a critical role in proliferation, migration and tamoxifen-inhibited growth of ER-positive breast cancer cells. Oncogenesis. 2018;7(12):98. https://doi.org/10.1038/s413 89-018-0107-x.

48. Nallanthighal S, Heiserman JP, Cheon DJ. The role of the extracellular matrix in Cancer Stemness. Front Cell Dev Biol. 2019;7:86. https://doi.org/10.3389/ fcell.2019.00086

49. Belkin AM, Stepp MA. Integrins as receptors for laminins. Microsc Res Tech. 2000;51(3):280-301.

50. Ramovs $V$, Te Molder $L$, Sonnenberg $A$. The opposing roles of lamininbinding integrins in cancer. Matrix Biol. 2017;57-58:213-43. https://doi.org/1 0.1016/.matbio.2016.08.007.

51. Cho S. CD36 as a therapeutic target for endothelial dysfunction in stroke. Curr Pharm Des. 2012;18(25):3721-30. https://doi.org/10.2174/138161212802 002760 .

\section{Publisher's Note}

Springer Nature remains neutral with regard to jurisdictional claims in published maps and institutional affiliations.
Ready to submit your research? Choose BMC and benefit from:

- fast, convenient online submission

- thorough peer review by experienced researchers in your field

- rapid publication on acceptance

- support for research data, including large and complex data types

- gold Open Access which fosters wider collaboration and increased citations

- maximum visibility for your research: over $100 \mathrm{M}$ website views per year

At $\mathrm{BMC}$, research is always in progress.

Learn more biomedcentral.com/submission 